\title{
IbM Pengrajin Anyaman Rotan di Kabupaten Jember: Upaya Peningkatan Kualitas dan Kuantitas Produksi
}

\author{
Rike Oktarianti, Kartika Senjarini, Mahriani \\ Fakultas Matematika dan Ilmu Pengetahuan Alam, Universitas Jember \\ rike.oktarianti@yahoo.com
}

\begin{abstract}
Abstrak
Salah satu industri kecil yang berkembang di desa Muktisari, kelurahan Tegal Besar, kecamatan Kaliwates, dan desa Mlokorejo-kecamatan Puger, kabupaten Jember adalah industri kerajinan anyaman rotan. Usaha tersebut masih berskala industri rumah tangga, namun mampu memberdayakan warga sekitarnya terutama kaum ibu. Permasalahan yang dihadapi oleh kedua mitra tersebut adalah tidak tersedianya peralatan yang memadai dalam mendukung produksi baik pada tahap persiapan maupun pada proses perakitan. Sehingga berdampak pada jumlah dan kualitas produksi tidak optimal. Berdasarkan permasalahan yang dihadapi oleh kedua mitra tersebut, maka program IbM ini bertujuan untuk mengimplementasikan teknologi tepat guna dan tepat sasaran berupa bantuan mesin serut dan irat rotan serta pelatihan dan pendampingan desain anyaman rotan. Hasil monitoring dan evaluasi yang dilakukan, menunjukkan dampak positif yang cukup signifikan terhadap kuantitas dan kualitas produksi anyaman rotan dibandingkan sebelum ada kegiatan IbM. Implementasi teknologi tepat guna dan tepat sasaran untuk berupa mesin/alat serut dan irat rotan mampu meningkatkan produksi anyaman rotan dari 500 per minggu bisa meningkatkan kuantitas menjadi 2 kali lipat sekitar 1000 per minggu. Kualitas anyaman rotan juga menunjukkan perbaikan ditunjukkan dengan jumlah anyaman rotan yang dikirim ke pihak eksportir lebih dari 85\% bisa lolos memenuhi standar ekspor.
\end{abstract}

Kata kunci: Pengrajin Anyaman Rotan, Kabupaten Jember

\section{PENDAHULUAN}

Industri kecil merupakan salah satu komponen yang mempunyai sumbangan cukup besar dalam menciptakan lapangan pekerjaan dan pemerataan pendapatan di Indonesia. Keberhasilan industri kecil yang berkembang di suatu daerah pada umumnya mampu memberikan kontribusi kepada daerah atau lingkungan sekitarnya. Usaha kecil yang berkembang pada umumnya merupakan usaha rumah tangga (home industy) yang sebagian besar masih bercampur dengan tempat tinggalnya, dan masih memerlukan pembinaan yang terus-menerus agar masalah yang dihadapi seperti permodalan dan pengelolaan dapat diatasi .

Berkembangnya industri kecil dilatarbelakangi oleh penduduk Indonesia yang tingkat pendidikannya relatif rendah serta mempunyai sedikit modal. Hal ini berdampak pada terbatasnya kegiatan ekonomi masyarakat, terutama bagi masyarakat yang mulai memasuki usia kerja, tanpa adanya bekal pendidikan serta modal yang 
cukup, maka pilihannya adalah bekerja atau membuka lapangan kerja di sektor industri kecil. Industri kecil ini berkembang pesat, disebabkan modal yang diperlukan tidak besar dan dapat menyerap banyak tenaga kerja serta mempunyai peran strategis mengingat berbagai potensi yang dimiliki terutama dalam meningkatkan kesejahteraan masyarakat. Potensi tersebut antara lain mencakup jumlah dan penyebaran industri kecil penyerapan tenaga kerja yang besar, penggunaan bahan baku lokal, dan ketahanannya terhadap krisis.

Salah satu industri kecil yang berkembang di Muktisari, kelurahan Tegal Besar, kecamatan Kaliwates dan di desa Mlokorejo- kecamatan Puger, kabupaten Jember adalah industri kerajinan anyaman rotan, dengan produk utamanya berupa keranjang dan sejenis nampan yang berorientasi ekspor. Pemilik usaha yang di Muktisari adalah ibu Siti Khotimah yang sekaligus sebagai ketua kelompok pengrajin anyaman rotan yang beranggotakan beberapa pengrajin. Salah satu anggota pengrajin tersebut adalah yang berdomisili di desa Mlokorejo, kecamatan Puger, kabupaten Jember. Bahan baku berupa rotan diambil dari daerah lain terutama dari daerah Gresik. Kedua mitra tersebut sudah melakukan kegiatan produksi selama kurang lebih satu tahun, dengan dibantu beberapa karyawan tetap dan juga mampu memberdayakan warga sekitarnya terutama ibu-ibu. Ibu-ibu yang terlibat dalam proses produksi pada umumnya mengerjakan anyaman dengan cara membawa pekerjaan tersebut di rumah sehingga bisa dikerjakan secara sambilan. Produksi kerajinan anyaman yang mampu dihasilkan kedua mitra tersebut masing-masing perminggu sekitar 500 buah, dari yang ditargetkan oleh pihak eksportir sebesar 1500 buah per minggu. Target belum bisa dicapai karena terdapat beberapa permasalahan yang menghambat produksi, baik pada tahap persiapan maupun perakitan.

Dalam rangka untuk memenuhi target dari eksportir, maka diperlukan upaya peningkatan kuantitas maupun kualitas produksi anyaman rotan pada kedua mitra tersebut. diperlukan sebuah penerapan teknologi tepat guna dan tepat sasaran yang berupa alat pengirat untuk menghaluskan rotan. Pengerjaan anyaman rotan meliputi tahapan persiapan bahan baku dengan menyediakan kayu sebagai kerangka dan rotan yang akan dianyam. Tahap berikutnya adalah tahapan penganyaman rotan dan finishing. Semua tahapan tersebut dipengaruhi oleh ketersediaan peralatan yang memadai. Peralatan yang memadai dalam hal ini adalah untuk mendukung efektivitas dan efisiensi produksi. Tersedianya peralatan pengirat (penghalus) bilah rotan dan alat penjepret (tembak) sangat diperlukan, selama ini proses produksi anyaman rotan masih menggunakan teknologi tradisional (manual). Selain itu ketersediaan alat penjepret pada proses perakitan untuk mengaitkan kerangka dengan rotan jumlah sangat terbatas dan dirasakan masih sangat kurang mengingat jumlah warga yang terlibat dalam pengerjaan anyaman relatif banyak. Akibatnya hasil produksi tidak dapat maksimal dan kualitas produk masih perlu ditingkatkan, demikian juga waktu yang dibutuhkan untuk penyelesaiannya pekerjaan masih relatif lama. Demikian juga dari segi desain, produk kerajinan anyaman rotan ini masih sederhana kurang inovasi dan variasi, sehingga diperlukan program pelatihan dan pendampingan untuk memperkaya desain supaya lebih diminati oleh konsumen. Program ini ditujukan untuk membantu memecahkan masalah yang dihadapi oleh mitra yaitu pengrajin rotan di Muktisari dan Mlokorejo di kabupaten Jember.

Metode yang akan digunakan untuk mengatasi permasalah pada mitra adalah bantuan peralatan/mesin serut dan irat rotan untuk peningkatan efisiensi waktu pada proses persiapan bahan Diharapkan peralatan tersebut dapat meningkatkan kualitas dan kuantitas produk yang dihasilkan. Di samping itu juga akan dilakukan pelatihan 
dan pendampingan terkait desain produk. Secara detail, ada beberapa metode yang digunakan. Pertama, tim pengusul IbM merancang alat/mesin serut dan irat rotan yang dibutuhkan oleh mitra. Kedua, pemberian modal usaha berupa bantuan alat/mesin serut dan irat rotan untuk mempercepat proses produksi. Tim pengusul IbM juga melakukan pendampingan tata cara penggunaan bantuan peralatan tersebut sehingga mitra mampu mengoperasikannya. Ketiga, pelatihan dan pendampingan kepada mitra dalam hal desain anyaman rotan sehingga produk yang dihasilkan mitra lebih bervariasi dan mampu menarik minat konsumen. Keempat, monitoring dan evaluasi terhadap program IbM, memonitoring kegiatan untuk mengetahui keberhasilan program. Melakukan evaluasi yang pada dasarnya adalah memberikan pertimbangan atau nilai berdasarkan kriteria tertentu. Pada kegiatan ini, rancangan evaluasi yang digunakan untuk menilai keberhasilan kegiatan berupa penilaian terhadap pencapaian target program.

Pendampingan dilakukan dengan supervisi penerapan keterampilan yang diberikan dalam pelatihan untuk memastikan bahwa keterampilan yang diberikan benar-benar diimplementasikan. Dampak dari segi ekonomi yang diharapkan dari kegiatan ini yaitu meningkatnya kuantitas dan kualitas produksi anyaman rotan yang akan meningkatkan pendapatan mitra dan menambah lapangan kerja baru bagi warga di sekitarnya. Selain dampak ekonomi, dampak bidang IPTEK yang diharapkan yaitu terjadinya transfer ilmu (alih teknologi) antara PT dengan masyarakat.

\section{PEMBAHASAN}

Berdasarkan permasalahan yang teridentifikasi pada mitra pengarajin anyaman rotan di Muktisari dan Mlokorejo, kabupaten Jember, maka kegiatan program IbM ini difokuskan dalam kegiatan implemementasi teknologi tepat guna dan tepat sasaran berupa peralatan serut dan irat bilah rotan dalam membantu proses penghalusan rotan untuk pembuatan anyaman. Penerapan teknologi ini upaya menggantikan metode manual yang dilakukan oleh pengrajin tersebut. Diharapkan proses pembuatan anyaman rotan lebih efisien dan efektif dari segi waktu dan memberikan hasil yang memuaskan dan berdampak pada peningkatan kualitas dan kuantitas produk. Kegiatan kedua adalah pendampingan desain produk anyaman rotan bertujuan meningkatkan keragaman desain produk, sehingga produk menjadi lebih menarik dan banyak diminati konsumen. Diharapkan dengan pendampingan ini akan tercapai diversifikasi produk.

Hasil monitoring dan evaluasi yang dilakukan terhadap kegiatan IbM pada pengrajin anyaman rotan tersebut di atas menunjukkan bahwa luaran yang dicapai sesuai dengan target yang diajukan. Kegiatan IbM berdampak positif terhadap peningkatan kuantitas dan kualitas produksi anyaman rotan dari dua mitra. Target dari implementasi peralatan teknologi tepat guna dan tepat sasaran berupa alat serut dan pengirat rotan, maka luaran yang dihasilkan adalah berupa produk alat/mesin teknologi tepat guna berupa mesin serut dan irat rotan, untuk mempercepat proses produksi dan peningkatan kualitas rotan (gambar l). 

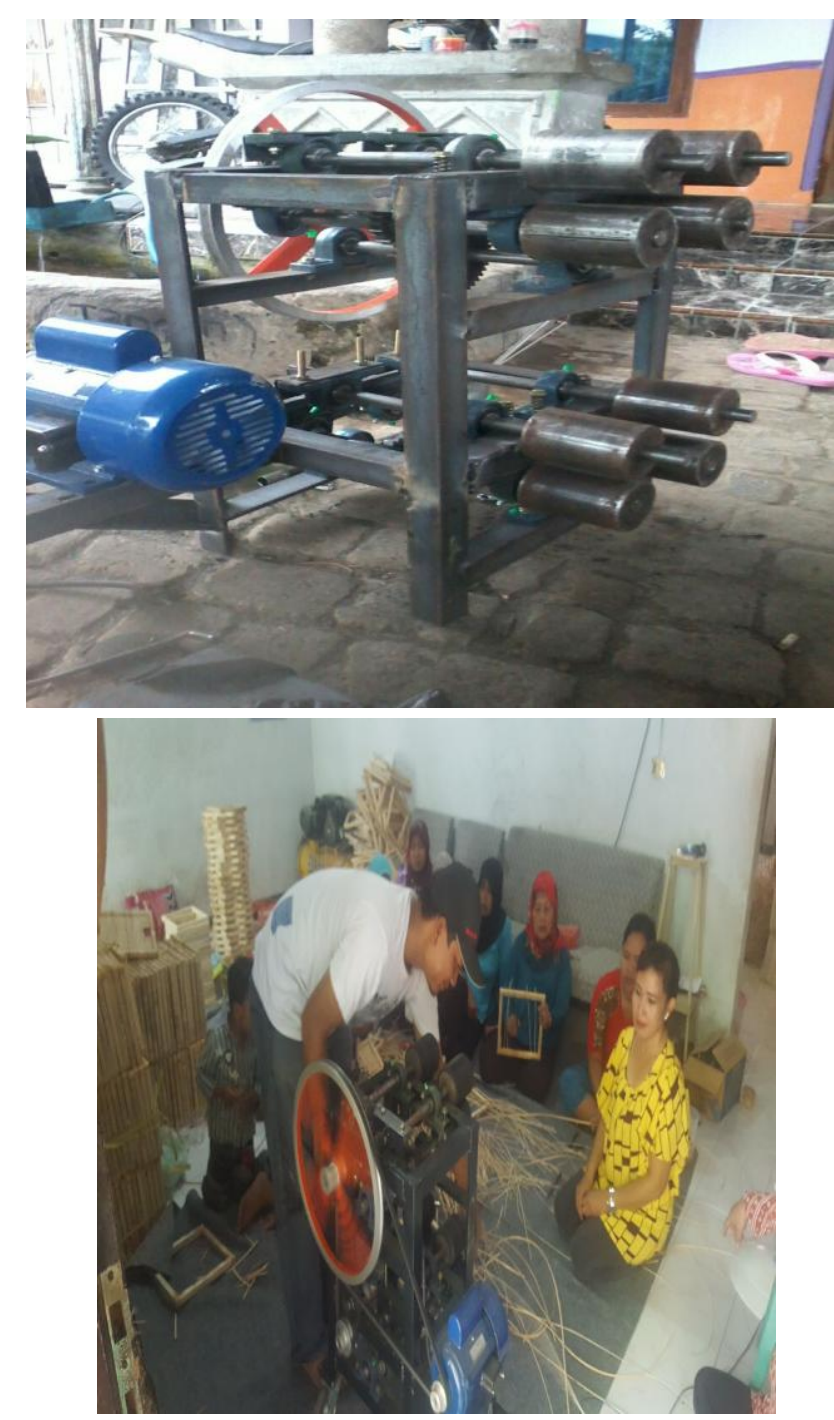

Gambar 1. Mesin serut dan irat rotan \& pendampingan penggunaan mesin serut dan irat

Target kedua berupa peningkatan kualitas dan diversifikasi produk anyaman dengan pelatihan dan pendampingan dengan memberikan inovasi dan kreatifitas desain anyaman (gambar 2). Luaran yang dihasilkan berupa peningkatan kualitas dan produk anyaman rotan yang lebih variatif dan inovatif (gambar 3) serta peningkatan soft-skill mitra dan warga sekitar. 


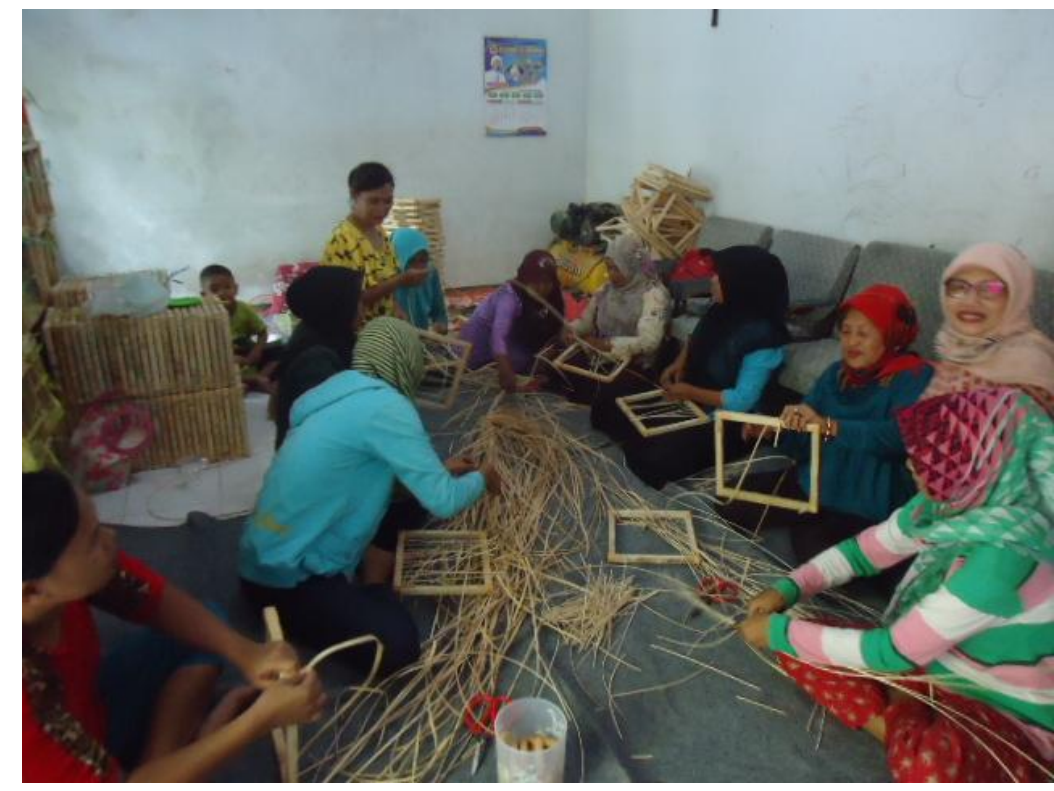

Gambar 2. Pelatihan dan pendampingan desain anyaman rotan
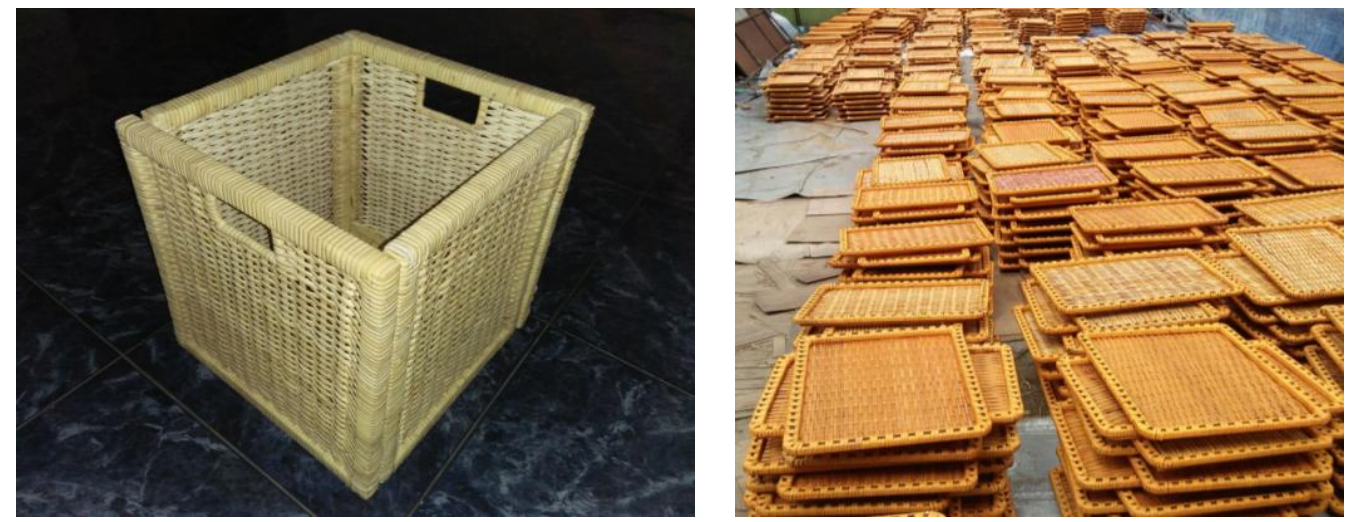

Gambar 3. Produk anyaman rotan mitra

Target ketiga berupa peningkatan jumlah (kuantitas) dan kualitas produk anyaman dapat tercapai dengan meningkatnya jumlah produk anyaman yang dihasilkan oleh mitra meningkat dua kali lipat menjadi 1000 buah per minggu dan kualitas anyaman menjadi lebih baik 85\% lolos diterima pihak eksportir memenuhi standar ekspor. Diharapkan hasil kegiatan IbM ini dapat meningkatkan pendapatan dan kesejahteraan pengrajin anyaman rotan khususnya di daerah Muktisari dan Mlokorejo dan warga sekitar yang terlibat dalam pembuatan anyaman rotan.

\section{KESIMPULAN}

Kegiatan IbM pengrajin anyaman rotan di kabupaten Jember upaya peningkatan kualitas dan kuantitas produksi terlaksana dengan baik, luaran yang dicapai sesuai dengan traget. Kegiatan IbM berdampak positif dan cukup signifikan terhadap (1) peningkatan soft skill mitra dan warga sekitar dalam penggunaan alat untuk mempercepat proses produksi dan peningkatan kualitas anyaman rotan dan (2) mitra 
mampu meningkatkan produksi anyaman rotan yang awalnya 500 per minggu bisa meningkatkan produk menjadi 2 kali lipat sekitar 1000 per minggu. Kualitas anyaman rotan yang dikirim ke pihak eksportir lebih dari $85 \%$ bisa lolos memenuhi standar ekspor.

\section{DAFTAR PUSTAKA}

Kasmudjo. 2013. Rotan dan Bambu. Yogyakarta: Cakrawala Media.

Kiyokatsu Suga dan Sularso, 1979. Dasar Perencanaan dan Pemilihan Elemen Mesin. PT.Pradnya Paramita, Jakarta.

Marizar, S. E. 2005. Design Furniture. Yogyakarta: Media Pressindo.

Marizar, S. E. 2007. Serial Rumah: Rotan dan Material Unik. Jakarta: Gramedia.

Soedjono. 1999. Berkreasi dengan Rotan. Bandung: Remaja Rosadakarya.

Soedjono, dan Srinuryani, E. 2008. Kerajinan Rotan. Bandung: Angkasa 